\title{
The use of active subtitling activities for students of Tourism in order to improve their English writing production
}

\author{
José Javier Ávila-Cabrera \& Pilar Rodríguez-Arancón \\ Universidad Complutense de Madrid (UCM) \& UNED-Universidad Nacional \\ de Educación a Distancia (Spain) \\ josejaav@ucm.es, prodriguez@flog.uned.es
}

\section{Abstract}

Most current university students are permanently surrounded by multimedia content, especially in their leisure time, and this is affecting their attention span and the way in which they communicate and learn. As teachers/researchers it is both challenging and rewarding for us to create activities that keep them motivated and focused, therefore we must adapt our courses in order to achieve the expected results, trying to take advantage of what interests students whilst ensuring that their skills are clearly developed. Audiovisual translation can be useful in this scenario when it is integrated in the learning process as a tool, with a pedagogical objective: that is, as a means to an end.

This is the goal that a group of researchers from UCM, UNED and UAM aimed for when designing this project: to take advantage of the interest of a group of university students in multimedia content and ICT. All the activities were developed with a definite purpose -that of the improvement of writing skills in English and the use of specific vocabulary related to their degree in Tourism-. The students undertook reverse subtitling activities before handing in written compositions at several stages of the project. The researchers gathered data about the effect that these reverse subtitling activities had on the improvement experienced by the students in their writing skills and compared them to the performance of a control group.

Keywords: English for specific purposes, reverse subtitling, foreign language learning, writing production, tourism. 


\section{Resumen}

El uso de actividades de subtitulación activa para estudiantes de Turismo con el fin de mejorar su producción escrita en inglés

La mayor parte de los alumnos universitarios están inmersos en contenidos multimedia, en especial durante su tiempo libre, y esto puede afectar su atención, su manera de comunicarse y de aprender. Como docentes/investigadores resulta gratificante, a la vez que un reto, el diseñar actividades que puedan mantenerlos motivados y centrados. Esto nos obliga a adaptar nuestros cursos para que les ayuden a alcanzar una serie de resultados, aprovechando sus intereses y asegurando el desarrollo de sus destrezas. En este contexto, la traducción audiovisual resulta de utilidad cuando se integra como herramienta en el proceso de aprendizaje, con un objetivo pedagógico, es decir, como medio para obtener un fin.

Este fue el objetivo de un grupo de investigadores de la UCM, la UNED y la UAM a la hora de diseñar este proyecto: aprovechar el interés por los contenidos multimedia y las TIC de un grupo de alumnos universitarios. Todas las actividades se crearon con un claro objetivo: la mejora de las destrezas de producción escrita en lengua inglesa, así como el uso de vocabulario específico del Grado de Turismo. Los alumnos llevaron a cabo actividades de subtitulación antes de la entrega de actividades de producción escrita a lo largo del proyecto. Los investigadores recopilaron datos sobre el efecto que dichas actividades de subtitulación inversa tuvieron en la mejora de su expresión escrita y compararon los resultados con los de un grupo de control.

Palabras clave: Inglés para fines específicos, subtitulación inversa, aprendizaje de lenguas extranjeras, producción escrita, turismo.

\section{Introduction}

Audiovisual translation (AV'T) is now very widespread and has become much better known due to the vast number of audiovisual genres (films, TV series, documentaries, cartoons, etc.) and media (cinema, TV, DVD, Blu-ray, Internet platforms, mobile technology, etc.) which are available for users to consume at home or on the move. More and more lecturers and teachers are receiving education on AVT in order to be competent in the field of foreign language learning (FLL), making use of diverse AVT modes (subtitling, dubbing, voiceover, accessibility, etc.) which can be used as pedagogical tools in their classes. Díaz Cintas (2019) reviews the progress that this discipline has experienced in the last few decades. We are in fact witnessing a flourishing era in the field of AVT both professionally and in academia. 
In the FLL context, AVT research is a fruitful reality as can be seen in the multiple publications conducted at an international level (Baños Piñero \& Díaz Cintas, 2015; Talaván, 2016; Martínez Sierra \& Zabalbeascoa Terran, 2017; Chaume, 2018; Sokoli, 2018; Díaz-Cintas, 2019; Romero Fresco, 2019). There are several reasons why many of these studies are successful when carried out within the university context. Firstly, for undergraduates, many of whom are millennials (1981-1996) and post-millennials (1997-present), the consumption of audiovisual content on their mobile phones and tablets is second nature. Secondly, they tend to enjoy carrying out activities which involve the use of audiovisual content instead of the more traditional exercises typically used in foreign language (L2) classes. Thirdly, using AVT modes in the class is a motivating factor as well as being an entertaining activity, which ultimately allows students to foster different L2 skills (Talaván, 2013), including the development of cultural awareness.

This paper presents the project called SubESPSKills (Subtitling tasks in the English for Specific Purposes class to improve written production skills), which was implemented at the Universidad Complutense de Madrid (UCM) in Spain. The population was composed of students enrolled in the first course of English for Specific Purposes (ESP) of the Degree in Tourism. One of the major goals was to prove whether the use of active reverse subtitling can positively influence the participants' writing production skills in English. The manner in which this project was developed will be thoroughly addressed in the following sections.

\section{Theoretical framework}

Although the idea that translation can be a helpful tool to learn an L2 was questioned for several decades, possibly due to the limitations of the grammar-translation method (de Bot et al., 2005), it has now been reassessed as a practice that has made its way back into the FLL classrooms. AVT began to be used as a didactic tool in FLL in the 1980s in linguistic labs (Vanderplank, 2016) and its academic and pedagogical interest has recently experienced significant growth (Baños Piñero \& Díaz Cintas, 2015; Lertola, 2019). Since the beginning of the 21 st century, AVT has been studied in its more active application, that is, as a hands-on learning practice which enables students to make use of technology and helps them to develop different competences in an L2. 
One of the reasons for this new perspective could be the way in which the Common European Framework of Reference for Languages (CEFR) (Council of Europe, 2001: 14) has referred to translation and interpretation as legitimised forms of mediation in the L2 classroom: "In both the receptive and productive modes, the written and/or oral activities of mediation make communication possible $[\ldots]$ and occupy an important place in the normal linguistic functioning of our societies". Therefore, the use of the mother tongue in the L2 class can be a positive contribution as we are surrounded by translation on the Internet and in many audiovisual products which are common in our daily lives.

The use of video in the FLL classroom has had a direct and positive effect on students as a motivating and varied tool that is both instructive and entertaining (Vanderplank, 2010; Thaler, 2014; González-Vera \& Hornero Corisco, 2016; Herrero et al., 2018). Nowadays we can say that we are immersed in a digital and audiovisual revolution (Chaume, 2018; Díaz Cintas, 2018) and in the case of subtitling, it is now possible for a student to manipulate a video thanks to the development of free software that makes the inclusion of subtitles in the image, not only possible but easy. An example of this is the subtitling editor LRN-2sub, created by Roales Ruiz (2017, 2018).

In order to gather how useful AVT can be for FLL, research has been carried out in an array of its modalities, such as subtitling (Talaván, 2013; Gambier et al., 2015), dubbing (Danan, 2015; Sánchez Requena, 2016; Talaván \& Costal, 2017), audiodescription (Talaván \& Lertola, 2016; Navarrete, 2018), fansubbing (Bolaños-García-Escribano, 2017), etc. These pieces of research have focussed on the development of different skills: speaking (Talaván \& Ávila-Cabrera, 2015), writing (Ávila-Cabrera \& Corral Esteban, 2021), listening comprehension (Talaván, 2011; Talaván \& Rodríguez-Arancón, 2014a), etc. and all the results produced promising results, which calls for the transfer of these practices to new teaching levels and contexts.

In the present study the focus is on subtitling, which can be effected in several combinations: interlinguistic (L2-L1), intralinguistic (L2-L2) or as subtitling for the deaf and the hard of hearing. More specifically, this piece of research will analyse the outcomes that the production of reverse subtitles (Ávila-Cabrera, 2021), that is, the interlingual activity of creating L2 subtitles for a native language (L1) dialogue, has in a group of students. They were asked to subtitle some videos from Spanish or Chinese, whichever of 
the two their L1 happened to be, into English. In order to carry out these tasks they had to consider strategies of condensation as messages needed to be adapted so as to fit in with the images in a coherent and synchronised way.

This modality has been researched previously with different objectives (Fazilatfar et al., 2011; Laviosa, 2014; Lertola \& Mariotti, 2017; Talaván et al., 2019), but always through the direct experience of the students in tasks that conform to a complete didactic context involving image, sound, translation and the use of technology. It offers the added value of involving the student in real tasks with an authentic purpose that are very similar to professional work, as most of it is now carried out online (Bolaños-García-Escribano, 2018), and with many of the same characteristics and constrictions.

The purpose of the study is not to train students as professional subtitlers, therefore, only the basic rules of good practice were highlighted in class. However, it was essential for them to find alternatives to the spoken dialogue in order to achieve the conciseness and cohesion of the message by rephrasing the content, searching for synonyms for the words or expressions so as to adapt to the timing and synchronicity with regards to the images, and even being alert to matters such as register, style, spelling and cultural aspects that could influence the understanding of the message in the L2. All of this must be taken into account while respecting the core message of the original (Ragni, 2018: 15).

In summary, they had to learn that subtitling is not the same as the production of a dialogue transcription, as the viewer needs to be able to read without missing visual information shown on the screen. That is the reason why it is an effective practice for students to improve their writing skills (Talaván \& Rodríguez-Arancón, 2014b). The task of reverse subtitling, manipulating the original audio track, has to be performed while taking many other factors into consideration thus naturally highlighting the differences between L1 and L2 in a contrastive effort. For this reason, it has been shown to increase language awareness (Scheffler, 2013).

'Active' production skills, such as speaking or writing, are more problematic for learners to master than 'passive' ones (Laufer \& Girsai, 2008) as they require more in-depth knowledge of the language and attention to details such as pronunciation or intonation (in the case of speaking), or spelling (in the case of writing). However, as a consequence of the extra effort needed, words and expressions that are acquired productively, that is, through active language use, are less likely to be forgotten than those acquired passively 
(Schmitt, 1998), providing a further argument in support of the use of didactic subtitling in FLL (Ragni, 2018: 17).

\section{The project}

This piece of research is based on a teaching innovation project which was implemented in the first semester of the 2018-2019 academic course at the UCM. With the aim of creating a collaborative network, the coordinator counted on the help of lecturers from other public universities as well as on two students whose native language is Chinese, since their help was required with the activities designed in their L1. As the project concerns students doing the Tourism Degree, their activities are oriented to the language commonly used in the tourism industry.

\subsection{Objectives}

There are various goals within this project which are presented under two research questions as shown below:

- Does reverse subtitling help students to improve their written skills in ESP?

This question is to be addressed by looking into the marks obtained in the tasks explained below.

1) The students submitted three compositions during face-to-face lab classes. This includes both the experimental and the control groups.

2) The experimental group students also worked on two active subtitling activities after the submission of each of the first and the second compositions. These AVT tasks were used as the means to observe whether the final goal was achieved, that is, the improvement in their compositions in the English language mainly within the scope of tourism. This question is addressed through the quantitative information gathered.

- What other skills can students improve through the use of reverse subtitling? 
The participants of the experimental group filled out an online prequestionnaire with general questions about their linguistic profile, audiovisual content consumption, etc. In addition, after the completion of the activities, the students answered an online post-questionnaire with specific questions on their participation in the project. All of this data was analysed qualitatively.

\subsection{Methodology}

The project was presented to the students of the Tourism Degree who were taking their first ESP course. They were told that up to 25 participants could be part of the experiment and that those who completed all the tasks would be given an extra point which would be added to their overall mark, although they would need to get at least 4 (or $40 \%$ ) in their final mark before this could be taken into account.

This is a case study in which the population is the experimental group, considering that observation is mainly centred on the participants of the study. We used a mixed methodology (Robson \& McCartan, 2016), inasmuch as we gathered quantitative data, both from the three compositions submitted and also the subtitling tasks carried out. The subtitling tasks were used as the medium for achieving the goal, although they were also assessed in order to elicit whether any improvements were perceptible. Also, qualitative data was gathered through a pre-questionnaire submitted at the beginning of the course and a post-questionnaire completed after the end of the project. Hence, the quantitative data was analysed in the first place in order to be able to corroborate or refute findings, in an example of sequential explanatory design research (Creswell, 2003).

In order to be able to work collaboratively, there were other lecturers who participated in this project. There were 3 lecturers from the UCM, including the coordinator, 3 from the Universidad Nacional de Educación a Distancia (UNED), and 1 lecturer from the Universidad Autónoma de Madrid (UAM), all of them public universities in Spain. Some of these researchers are experts in the fields of AVT in the FLL context and others in FLL, more concretely in ESP. Considering that the subtitling tasks involved subtitling from Spanish and Chinese into English, we needed the support of two Chinese students who helped with the transcripts of the videos from Chinese to English for assessment purposes. 


\subsection{Procedures}

The project was presented in the face-to-face class (an overall number of 70 students enrolled in English for Tourism) and also on the virtual campus so that all students could have access to the necessary information on how to proceed. However, the project was only open for 25 students. Those keen on participating had to submit the pre-questionnaire. Then a virtual community was created so students could be given further instructions. The different steps to follow were included in the virtual community as shown in Table 1:

- 10-23 September. Pre-questionnaire

- 24 September-7 October: Composition 1

- 8-21 October: Subtitle video 1

- 22 October-4 November: Composition 2

- 5-18 November: Subtitle video 2

- 19 November-2 December: Composition 3

- 3-16 December: Post-questionnaire

Table 1. Timeline of the project.

As soon as the deadline for each of the activities was reached, the researchers did the assessment (of the compositions as well as the subtitling activities) and sent feedback to the students before they moved onto the next stage. In this way, the participants could learn from their errors and limitations in an attempt to improve their performance in the following tasks.

The students could write the compositions in class during their allocated practice periods. The topics were related to the scope of tourism so that they would be useful in enhancing the students' command of the terminology of this area. The subtitling tasks were, nonetheless, done at home, as not all students in the subject were participating in this experiment. As students of Tourism, many of them were not familiar with AVT, so a class was used to teach them some general conventions (Talaván et al., 2016) as shown in Table 2. 
- The duration of subtitles on screen is 1-6 seconds.

- One-liners should contain up to some 35 characters.

- Two-liners should contain up to 70 .

- Condensation is a must and only the gist should appear in the subtitles.

- Subtitles must be properly segmented both semantically and syntactically, avoiding splitting the phrases between lines.

- Please see the BBC subtitle guidelines for further information: http://bbc.github.io/subtitle-guidelines/

Table 2. Lecture on subtitling conventions.

Special emphasis was placed on segmentation, taking into account that these subtleties were probably new to most of them. The students were given a number of examples which were properly segmented and others which were not, so that they could learn how to split the lines without separating phrases. This was a totally new concept for the majority of them.

As far as the subtitling editor was concerned, we opted for Aegisub because it can be considered not to be too complicated for someone who has never subtitled a video. Moreover, we uploaded a tutorial to the virtual campus so that the students could follow some instructions and steps during the subtitling process. If any of them had difficulties coping with the editor, there was a forum intended for technical questions, apart from some others of a diverse nature that they had at their disposal throughout the project.

There were two types of tasks which were assessed by the researchers. First, the compositions submitted (by both the experimental and control groups) were evaluated by the same lecturer in order to avoid subjectivity in the assessment of these tasks. The assessment was based on the Cambridge performance rubric for B1 level, as the coursebook they had in the subject was B1-B1+. ${ }^{1}$ This rubric follows a writing assessment scale based on the CEFR (Council of Europe, 2001), paying attention to four subscales: content (the candidate follows the instructions indicated in the task; see Appendix 1), communicative achievement (the candidate uses a register in accordance with the purpose of the task), organisation (the candidate's ideas are presented logically and in order) and language (the candidate's use of vocabulary and grammar), as indicated in Table 3. 


\begin{tabular}{|c|c|c|c|c|}
\hline B1 & CONTENT & $\begin{array}{l}\text { COMMUNICATIVE } \\
\text { ACHIEVEMENT }\end{array}$ & ORGANISATION & LANGUAGE \\
\hline 5 & $\begin{array}{l}\text { All content is relevant to the task. } \\
\text { Target reader is fully informed. }\end{array}$ & $\begin{array}{l}\text { Uses the conventions of the } \\
\text { communicative task to hold } \\
\text { the target reader's attention } \\
\text { and communicate } \\
\text { straightforward ideas. }\end{array}$ & $\begin{array}{l}\text { Text is generally well- } \\
\text { organised and coherent, using } \\
\text { a variety of linking words and } \\
\text { cohesive devices. }\end{array}$ & $\begin{array}{l}\text { Uses a range of everyday } \\
\text { vocabulary appropriately. } \\
\text { with occasional } \\
\text { inappropriate use of less } \\
\text { common lexis. } \\
\text { Uses a range of simple and } \\
\text { some complex grammatical } \\
\text { forms with a good degree of } \\
\text { control. } \\
\text { Errors do not impede } \\
\text { communication. }\end{array}$ \\
\hline 4 & \multicolumn{4}{|c|}{ Performance shares features of Bands 3 and 5 . } \\
\hline 3 & $\begin{array}{l}\text { Minor irrelevances and/or } \\
\text { omissions may be present. } \\
\text { Target reader is on the whole } \\
\text { informed. }\end{array}$ & $\begin{array}{l}\text { Uses the conventions of the } \\
\text { communicative task in } \\
\text { generally appropriate ways to } \\
\text { communicate straightforward } \\
\text { ideas. }\end{array}$ & $\begin{array}{l}\text { Text is connected and } \\
\text { coherent, using basic linking } \\
\text { words and a limited number of } \\
\text { cohesive devices. }\end{array}$ & $\begin{array}{l}\text { Uses everyday vocabulary } \\
\text { generally appropriately, } \\
\text { while occasionally overusing } \\
\text { certain lexis. } \\
\text { Uses simple grammatical } \\
\text { forms with a good degree of } \\
\text { control. } \\
\text { While errors are noticeable, } \\
\text { meaning can still be } \\
\text { determined. }\end{array}$ \\
\hline 2 & \multicolumn{4}{|c|}{ Performance shares features of Bands 1 and 3.} \\
\hline 1 & $\begin{array}{l}\text { Ifrelevances and misinterpretation } \\
\text { of task may be present. } \\
\text { Target reader is minimally } \\
\text { informed. }\end{array}$ & $\begin{array}{l}\text { Produces text that } \\
\text { communicates simple ideas in } \\
\text { simple ways. }\end{array}$ & $\begin{array}{l}\text { Text is connected using basic, } \\
\text { high-frequency linking words. }\end{array}$ & $\begin{array}{l}\text { Uses basic vocabulary } \\
\text { reasonably appropriately. } \\
\text { Uses simple grammatical } \\
\text { forms with some degree of } \\
\text { control. } \\
\text { Errors may impede meaning } \\
\text { at times. }\end{array}$ \\
\hline 0 & $\begin{array}{l}\text { Content is totally irrelevant. } \\
\text { Target reader is not informed. }\end{array}$ & \multicolumn{3}{|c|}{ Performance below Band 1.} \\
\hline
\end{tabular}

Table 3. Cambridge written performance rubric for B1 level.

Second, regarding the rubric for the subtitling tasks, although their assessment was mostly informative, since it was the actual tool for the potential improvement of writing production skills, it was based on and adapted from a previous project conducted at the UNED (2017) as can be seen in Table 4.

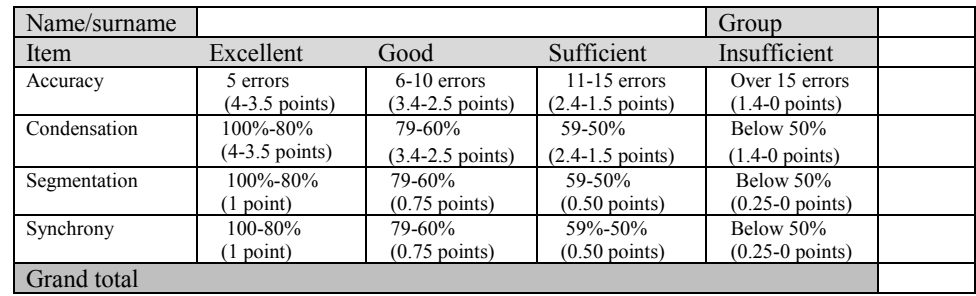

Table 4. Rubric for the assessment of the subtitling activities.

As illustrated in the above table, segmentation and synchrony were the items with the lower value, and this can be justified because this type of student was subtitling for the first time in most cases, so the evaluation rubric needed 
to be flexible in some of the technical aspects of this AVT mode. As for accuracy, this concerns the transfer from the source text (ST) to the target text (TT). Condensation accounts for the way of reducing the oral text into subtitles as only the gist must be included avoiding an excessive number of characters. In two-line subtitles, the segmentation or line break must maintain phrases unsplit. Semantic and syntactic considerations must be followed. Finally, the subtitles must appear on the screen during the time the audio is heard (between 1-6 seconds) thus achieving synchrony.

In an attempt to cover all the students' needs, as there was a majority of Spanish L1 and Chinese L1 speakers, we prepared different videos for the subtitling tasks. Some of them were in Spanish and others in Chinese to be subtitled into English. The two Chinese L1 students collaborating in the project helped the researchers to transfer the Chinese ST into the TT in English so that the video clips subtitled could be assessed as accurately as possible by the researchers (who were not L1 speakers of Chinese). Table 5 below shows the videos chosen by the researchers for the project, which are directly related to the field of tourism with the aim of allowing the participants to improve their written skills as well as their vocabulary inherent to the tourism sector, as previously mentioned.

$$
\begin{aligned}
& \text { - Video } 1 \text { (Spanish-English). Destinae Viajes [Destinae trips]. }{ }^{2} \\
& \text { - Video } 1 \text { (Chinese-English). 九寨沟 [Jiuzhai Valley]. }{ }^{3} \\
& \text { - } \quad \text { Video } 2 \text { (Spanish-English). Viaje a la Rioja }{\text { [Trip to La Rioja]. }{ }^{4}}^{4} \text { (Chinese-English). 西安 [Xi'an]. }{ }^{5}
\end{aligned}
$$

Table 5. Video clips subtitled.

Some excerpts from the translation done by the Chinese students can be seen in Table 6.

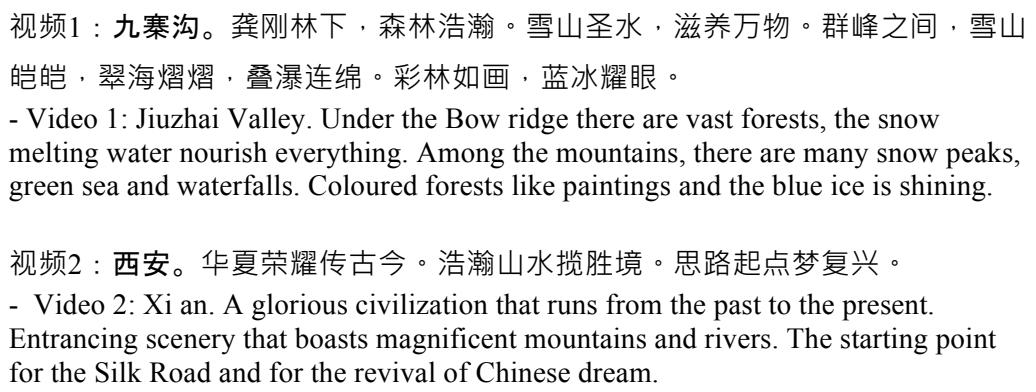

Table 6. Translation from the Chinese ST into the English TT. 
In addition, all the videos were cut to a duration of two minutes and thirty seconds. The reason for this is that if the video is short enough, participants will be more likely to carry out the activity, paying more attention and keeping up their interest (Talaván, 2013). As already explained, the majority of the L1 of the students were Spanish and Chinese, however, some students were from other European countries, but as their proficiency in Spanish can be considered to be B2 and C1 (although we did not count on linguistic evidence in the form of L2 certificates), they could work with the Spanish video clips smoothly and there was cultural diversity in the classroom.

\section{Analysis of data}

This section deals with all the data gathered during the course of the project. As a multi-strategy design, we aim for the triangulation of data via the analysis of quantitative and qualitative results. All these data are presented and explained here.

\subsection{Pre-questionnaire}

The participation in the project was open to up to 25 participants. However, 24 participants enrolled. Among the main reasons to participate, highlighted in the replies to the pre-questionnaire, were the fact that they enjoyed working with videos, it was important for them to be able to get an extra mark after the project, they seemed to be keen on learning how to subtitle videos, and they also acknowledged the need to improve their level of English, which was our primary goal in terms of the research being conducted.

The students were aged 18-21 (78.9\%) and 22-25 (21.1\%) and a majority were females $(62.2 \%)$ in relation to the number of males $(36.88 \%)$. As we have previously mentioned, $72.3 \%$ of the participants were Spanish L1 speakers, $21.7 \%$ Chinese and 6\% Erasmus students from other countries such as France and Italy. The levels of proficiency in English were mainly marked as A2, B1 and B2.

Regarding the consumption of audiovisual material with subtitles, there was a slight majority (that accounts for 52.6\%) who indicated that they always used them $(18.4 \%)$, most of the time (15.8\%), and often $(18.4 \%)$. By 
contrast, other participants (who account for 47.4\%) indicated sometimes (31.6\%), hardly ever (5.3\%) and never (10.5\%). When it comes to active subtitling (with AMARA, Aegisub, Subtitle Workshop, Clipflair, YouTube Video Editor, etc.), the majority (84.2\%) acknowledged that they had never subtitled any video versus $15.8 \%$ who had subtitled at some point in the past. We are addressing an experimental group who mostly had no experience in active subtitling as the data indicates.

\subsection{Quantitative data}

This section concerns quantitative information of paramount importance because the results obtained by the students are to be compared. Out of the 25 students who could have taken part, only 13 participants finished all the required tasks. Two samples of the different linguistic combinations of the video clips which were subtitled are shown in Figures 1 and 2.

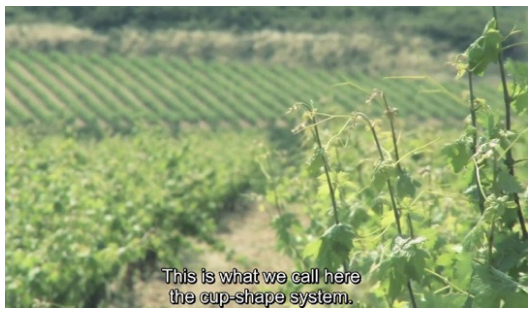

Figure 1. Example (Spanish-English) video 2.

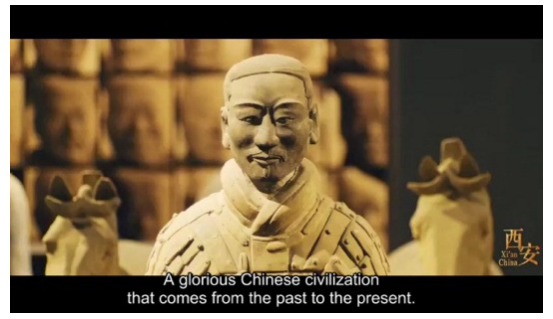

Figure 2. Example (Chinese-English) video 2.

In the first place, attention is paid to the results obtained in the subtitling tasks. This data is only used in order to be able to observe the progress made by the participants in the study, as Figure 3 illustrates.

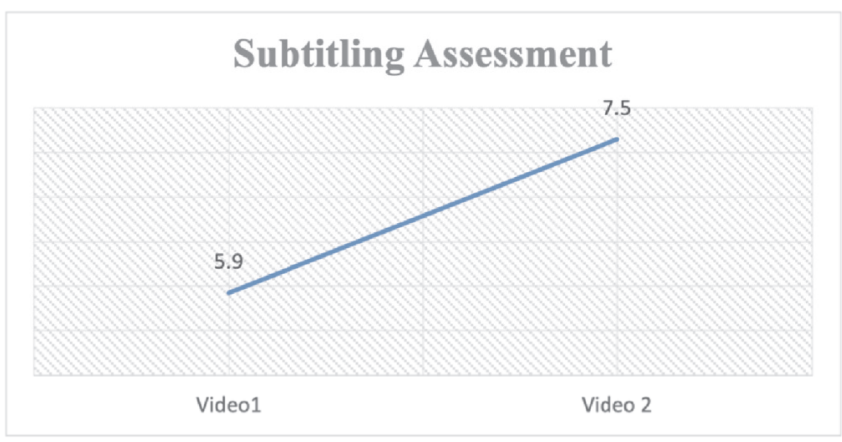

Figure 3. Results in the subtitling tasks. 
We can observe an improvement in the average mark of +1.6 (see Appendix 2). However, this finding is not conclusive as it can be assumed that the activity was motivating for the participants, and through the feedback received from the lecturers and their own effort they could improve the outcome of their second subtitling task.

As for the results obtained throughout the course on the compositions submitted, Figure 4 shows the average marks that the participants obtained.

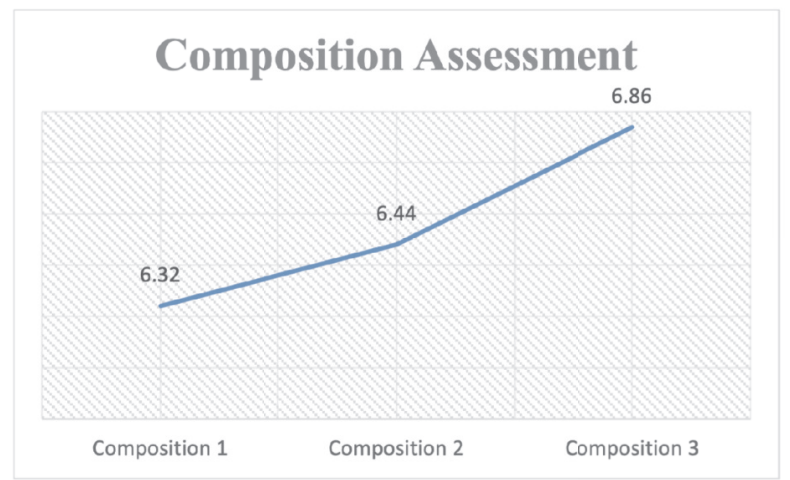

Figure 4. Results of the experimental group in the writing tasks.

We can observe positive progress in the composition assessments (see Appendix 3). It tends to be slight, but from the first to the third composition, there was an improvement of +0.54 . The interpretation of the above data leads us to state that the subtitling activities positively influenced the participants' writing production. It is clear that the improvement in the subtitling activities was more solid than that shown in the compositions, but the goal of this project may thus prove to be fulfilled in quantitative terms. The results of the control group, who worked on their compositions but without the extra participation in the project, that is, without undertaking any reverse subtitling activities, were different. However, it is important to note that both the experimental and control groups had other activities in common such as reading and listening comprehension, grammar and vocabulary tests, and creative revoicing tasks. Although the score of the control group for the first composition was higher (6.42) than that of the experimental group (6.32) and this situation could also be observed after the second composition was handed in and marked (6.53 vs. 6.44), it represented 
a narrower improvement of scores ( +0.11 vs. +0.12 respectively). However, the results for the third composition (6.62) showed an improvement in their writing skills, which is obviously expected while taking the course, but highlights the more positive outcome that the AVT activities had had in the experimental group.

Whilst the control group showed an increase in marks of +0.09 from compositions two to three, the experimental group more than quadrupled that improvement scoring +0.42 . It is worth noting that these results are associated with just two reverse subtitling activities within a two month period so that makes them the more remarkable. Both groups had 13 members, which means that the data were comparable. The results of the writing tasks by the control group (see Appendix 4) are illustrated in Figure 5.

\section{Composition Assessment}

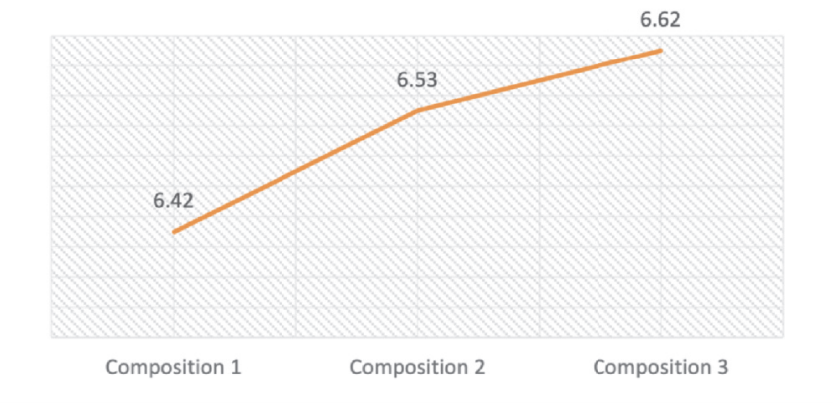

Figure 5. Results of the experimental group in the writing tasks.

In order to establish whether the results were statistically significant, a t-test was used with the marks obtained by the 26 students in the third piece of writing. A t-test is a very useful tool for comparing sets of numbers in order to demonstrate that the differences observed in a sample are larger than what would be expected from just random fluctuations. In this case, it was conducted in the unpaired form as in this study there are two separate sets of independent and identically distributed samples of students (the control and the experimental groups with 13 members in each). The results of both groups were significantly different, means being 6.6153 vs. 6.8615 and provided a figure of 0.711807 in the two-tailed test. Thus, it can be stated that the results, even though they are the outcome of a small sample of students, are statistically relevant. 


\subsection{Post-questionnaire}

The students' perceptions of the outcomes derived from their participation in this experiment are addressed here with the aim of observing whether there is any corroboration between quantitative and qualitative data.

The number of participants who dropped out during the project, which was a drawback for this study, had to do with the fact that some of them did not submit their compositions on time or because they missed one of the subtitling tasks.

In general, all the participants who filled out this post-questionnaire agreed on the fact that they were satisfied with their participation in the project. Regarding writing production, which was one of the main goals, the findings are shown in Figure 6.

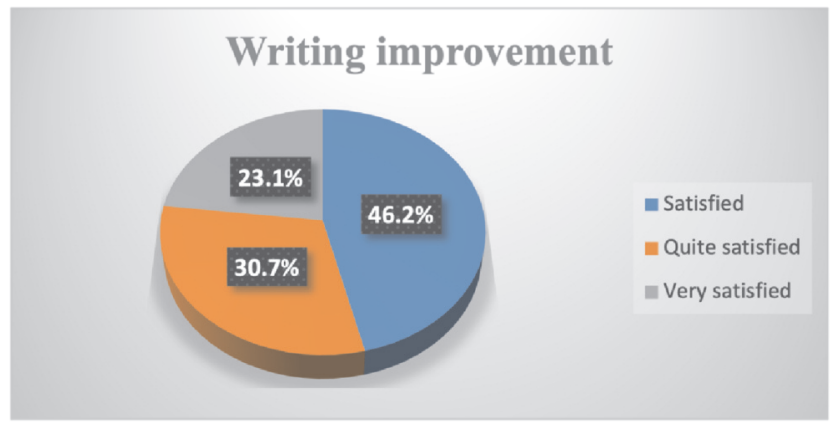

Figure 6. Students' perception of improvement of written skills.

It can be stated that the participants felt positive about their improvement in writing. This data also demonstrates how much they felt that they had improved in their subtitling tasks, which for the researchers is considered just an observation rather than a goal in itself. The emphasis is obviously given to the improvement derived from their written production in the form of compositions.

Apart from having focused on the enhancement of written skills, the participants were also asked about other skills which could have been improved. The answers to this question are included in Figure 7. 


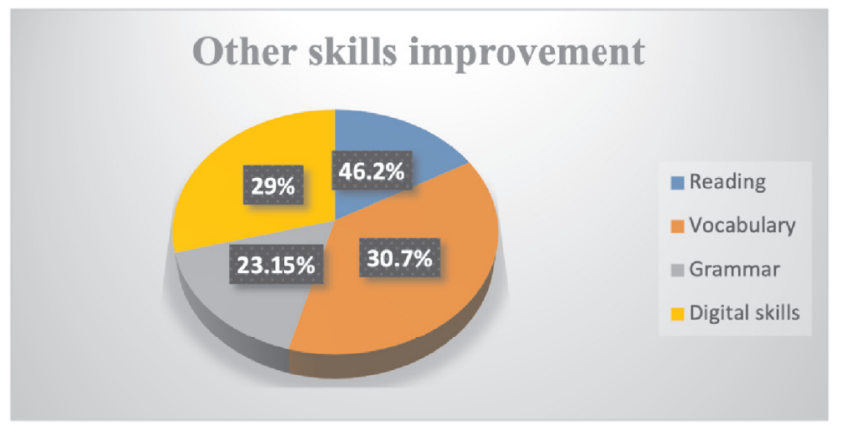

Figure 7. Students' perception of improvement of other skills.

As we can observe here the skill that was mentioned most often was reading, which could be the consequence of the revision of the subtitled version when transferring the ST, in Spanish or Chinese, into English. Vocabulary was the second one: the fact that the videos were related to their field (ESP in the tourism class) might have led the students to such a perception. In fact, they were asked if the subtitling activities had helped them improve their knowledge of English for Tourism. Here we used the Likert scale to avoid neutral answers (1 disagree -6 totally agree) and 12.5\% indicated scale number 4, 37.5\% opted for 5 and $50 \%$ chose 6 . Digital skills were also highlighted in the third place. This perception could be due to the use of technological tools such as the video clips, Aegisub as the subtitling editor and online dictionaries (when doing the subtitling tasks), for example. Grammar, however, was the fourth skill most mentioned.

There were some open questions so that the students could express their opinions in a more informal manner. Among them, we can highlight the following related to the aspects that they enjoyed most from the project: "A good way to introduce us into the 'subtitling world', which is a very entertaining way of learning the language"; "I liked all the aspects because it is a different way to learn English, not as always since I was little"; and "Entertainment and improve vocabulary". As for the weak aspects of the project some comments were: "Sometimes it was difficult to synchronise the subtitles with the audio", "The type of videos. I would have preferred other videos, but I know that we should work on tourism videos". Also, they were asked about some possible improvements for this project and considered: that they would have needed a more practical lecture on how to use Aegisub in class; they wanted to be able to choose their own videos, for example trailers or videos with everyday language; and they would like to add more 
videos instead of writing activities, which concerned the compositions that the researchers had to evaluate for validating the potential of active subtitling as a pedagogical tool.

In any case, further research could be conducted to look into all this qualitative data to obtain more insights into their answers and real outcomes, although it can be confirmed that there is a correlation between the students' own views in terms of linguistic improvement and the results obtained quantitatively.

\section{Discussion}

This piece of research aimed at answering two research questions, namely, whether the active practice of reverse subtitling from the Spanish or Chinese ST to the English TT could help improve the English writing skills of a group of students of Tourism; and what other skills could be affected by this type of activity at the same time, if any.

In order to answer both questions several data gathering tools were used. Pre- and post-questionnaires filled by the students before and after taking part in the experiment provided the researchers with some interesting qualitative data. The results were triangulated using the scores obtained by the students in the experimental group after each stage of the study, that is, the scores obtained on the subtitling tasks as well as each of the three compositions. These scores were produced by a combination of the marks given by the researchers for each activity using rubrics, and provided quantitative data.

However, only the scores obtained in the writing exercises were analysed further and compared between the experimental and control groups. These tasks help elicit the different effects in the marks that the extra reverse subtitling activities had in the experimental group members. An exact number of students (13) were randomly selected from the same class among those who had freely chosen not to take part in the experiment, so as to make a comparison between this control group and the participants in the experimental one.

Next, the decision to carry out a t-test was taken in order to highlight whether the results obtained by the experimental group of students were relevant, given the small sample that had taken part in the experiment from 
beginning to end. This test showed that the improvement, clearly experienced by both sets of students (in the control and the experimental groups) by following the course, was greater in those who had completed the AVT activities.

The second research question was answered in the post-questionnaire, where the participants selected their choices from the lists and the scores provided, and also contributed in the form of statements to the open-ended questions. They felt they had improved their reading skills, vocabulary knowledge, digital skills and grammar, in that order, and also that they had found this new way of learning an L2 interesting and rewarding.

Of course there were also some other aspects mentioned such as the difficulty in achieving synchronicity in the tasks. However, although enriching for the researchers' future projects, these do not affect the results of this study as the focus was not on mastering the process of performing those AVT tasks but on the consequences that those attempts would have on the improvement of the students' writing skills in English.

The observations, the scores obtained in all the tasks, the answers to the questionnaires, and the impressions reflected by the students who answered the open-ended questions once they had finished the study all seem to point in the same direction, towards considering the AVT activities as a motivating, fun and productive way to improve multiple skills in an L2 and specifically that of writing.

\section{Conclusion}

This paper has presented the results of SubESPSKills (Subtitling tasks in the English for Specific Purposes class to improve written production skills), a teaching innovation project which was centred on undergraduate students of the Tourism Degree from the UCM, Spain. Taking into account that the participants had different L1s, the activities not only concerned the transfer from a ST in Spanish, but also in Chinese (as the two most spoken L1s in the class) into a TT in English. Accordingly, we could address most of the participants' linguistic needs.

This experimental study has aimed to prove how active reverse subtitling can enhance a number of L2 skills in the students under analysis. If we observe the average marks in the subtitling practices, there was an improvement of 
+1.6 points. Although this datum is not conclusive, these practices were associated with an improvement in the compositions of +0.54 points. Although the students in the control group also showed a progressive improvement in their marks of the writing tasks, the difference was 0.11 between the first and second and +0.09 between the second and third, thus well below the experimental group results.

Observing the participants' perceptions in the qualitative data, we can talk about triangulation inasmuch as the results obtained quantitatively can be said to corroborate the qualitative data. The research questions of the project were therefore addressed and the goals justified and positively achieved.

As a limitation to this project, we can pinpoint that the initial number of students expected, 25, was considerably reduced to 13 , who were the ones who finished all the compulsory tasks. This is thus a study which shows some limited results in terms of the number of subjects under study, but which has proved the benefits of using reverse subtitling in FLL and more particularly in the ESP class, as is the case with numerous studies on AVT and FLL published so far. It is obvious that with a bigger population, more reliable results could have been obtained.

In short, offering the possibility of learning ESP making use of methodologies which include AVT modes is a common practice which is gaining more and more advocates among lecturers and teachers today. Students can be said to enjoy such practices more in the era of multimedia and multimodal content. The limits in the use of AVT in FLL are still unknown.

Article history:

Received 06 February 2020

Received in revised form 31 July 2020

Accepted 06 May 2021

\section{References}

Ávila-Cabrera, J. J. (2021). Reverse subtitling in the ESP class to improve written skills in English: Addressing international students' needs. Journal of Audiovisual Translation, 4(1), 27-49. https://doi. org/10.47476/jat.v4i1.2021.22 [10/04/21]

Ávila-Cabrera, J. J., \& Corral Esteban, A. (2021). The project SubESPSKills: Subtitling tasks for students of Business English to improve written production skills. English for Specific Purposes, 63, 33-44. https://doi.org/10.1016/j.esp.2021. $02.004[10 / 04 / 21]$

Baños Piñero, R., \& J. Díaz Cintas (Eds.) (2015). Audiovisual translation in a global context: Mapping an ever-changing landscape. Palgrave Macmillan.

Bolaños-García-Escribano, A. (2017). The effects of fansubs on EFL education for translation and 
interpreting students: An empirical approach. JoSTrans: The Journal of Specialised Translation, 28, 122-163. URL: https://www.jostrans.org/ issue28/art_bolanos.pdf [10/07/19]

Chaume, F. (2018). Is audiovisual translation putting the concept of translation up against the ropes? JoSTrans: Journal of Specialised Translation, 30, 84-104. URL: https://www. jostrans.org/issue30/art_chaume.pdf [10/07/19]

Council of Europe (2001). Common European Framework of Reference for languages (CEFR). URL: http://www.coe.int/t/dg4/linguistic/source/ Framework_EN.pdf. [10/07/19]

Creswell, J. W. (2003). Research design: Qualitative, quantitative, and mixed methods approaches (2nd ed.). Sage.

Danan, M. (2015). Subtitling as a language learning tool: Past findings, current applications, and future paths. In Y. Gambier, C. Mariotti \& A. M. Caimi (Eds.), Subtitles and language learning. Principles, strategies and practical experiences (pp. 41-61). Peter Lang.

De Bot, K., Lowie, W., \& Verspoor, M. (2005). Second language acquisition: An advanced resource book. Routledge.

Díaz Cintas, J. (2018). 'Subtitling's a carnival': New practices in cyberspace. JoSTrans: The Journal of Specialised Translation, 30, 127-149. URL: https://www.jostrans.org/issue30/art_ diazcintas. pdf [10/07/19]

Díaz-Cintas, J. (2019). Audiovisual translation in mercurial mediascapes. In M. Ji \& M. Oakes (Eds.), Advances in empirical translation studies (pp. 177-197). Cambridge University Press. URL: https://doi.org/10.1017/9781108525695 [10/07/19]

Fazilatfar, A. M., Ghorbani, S., \& Samavarchi, L. (2011). The effect of standard and reversed subtitling versus no subtitling mode on L2 vocabulary learning. The Journal of Teaching Language Skills (JTLS), 3(1), 43-64. URL: 10.22099/JTLS.2012.393 [10/07/19]

Gambier, Y., A. Caimi, \& C. Mariotti (Eds.) (2015). Subtitles and language learning. Principles, strategies and practical experiences. Peter Lang.

González-Vera, P., \& Hornero Corisco, A. (2016). Audiovisual materials: A way to reinforce listening skills in primary school teacher education. Language Value, 8(1), 1-25. URL: http://www. languagevalue.uji.es/index.php/languagevalue/arti cle/download/93/91 [10/07/19]

Herrero, C., Sánchez-Requena, A., \& Escobar, M. (2018). Una propuesta triple. Análisis fílmico, traducción audiovisual y enseñanza de lenguas extranjeras. InTRAlinea Special Issue: Building Bridges between Film Studies and Translation Studies, 19. URL: http://www.intralinea.org/ specials/article/2245 [10/07/19]

Laufer, B. \& Girsai, N. (2008). Form-focused instruction in second language vocabulary learning: A case for contrastive analysis and translation. Applied Linguistics, 29(4), 694-716. URL: $\quad$ https://doi.org/10.1093/applin/amn018 [10/07/19]

Laviosa, S. (2014). "Introduction". Translation in the language classroom: Theory, research and practice. The Interpreter and Translator, Trainer, 8(1), 1-7. URL: https://doi.org/10.1080/1750399X. 2014.908548 [10/07/19]

Lertola, J. (2019). Audiovisual translation in the foreign language classroom: Applications in teaching of English and other foreign languages. Research Publishing Net.

Lertola, J. \& Mariotti, C. (2017). Reverse dubbing and subtitling: Raising pragmatic awareness in Italian English as a second language (ESL) learners. The Journal of Specialised Translation, 28, 103-121. URL: https://www.jostrans.org /issue28/art_lertola.pdf [10/07/19]

Martínez Sierra, J. J., \& P. Zabalbeascoa Terran (Eds.) (2017). Translation of humour. MonTI. Monografías de Traducción e Interpretación, 9, 1-354. URL: https://doi.org/10.6035/MonTI.2017.9 [10/07/19]

Navarrete, M. (2018). The use of audio description in foreign language education. Translation and Translanguaging in Multilingual Contexts, 4(1), 129-150. URL: https://doi.org/10.1075/ttmc. 00007.nav [10/07/19]

Ragni, V. (2018). Didactic subtitling in the foreign language ( $F L)$ classroom. Improving language skills through task-based practice and formfocused instruction (FFI): Background considerations. Translation and Translanguaging in Multilingual Contexts, 4(1), 9-29. URL: https://doi.org/10.1075/ttmc.00002.rag [10/07/19]

Roales Ruiz, A. (2017). Técnicas para la traducción audiovisual: subtitulación. Escolar y mayo.

Roales Ruiz, A. (2018). Didáctica de la subtitulación: una propuesta tecnológica. Editorial Comares.

Robson, C., \& McCartan, K. (2016). Real world research (4th ed.). John Wiley \& Sons.

Romero Fresco, P. (2019). Accessible filmmaking: Integrating translation and accessibility into the filmmaking process. Routledge. 
Sánchez Requena, A. (2016). Audiovisual translation in teaching foreign languages: Contributions of dubbing to develop fluency and pronunciation in spontaneous conversations.

Porta Linguarum, 26, 9-21. URL: http://hispadoc. es/descarga/articulo/5784926.pdf [10/07/19]

Scheffler, P. (2013). Learners' perceptions of grammar-translation as consciousness raising. Language Awareness, 22(3), 255-269. URL: https://doi.org/10.1080/09658416.2012.703673 [10/07/19]

Schmitt, N. (1998). Tracking the incremental acquisition of second language vocabulary: A longitudinal study. Language Learning, 48(2), 281-317. URL: https://onlinelibrary.wiley.com/doi/ pdf/10.1111/1467-9922.00042 [10/07/19]

Sokoli, S. (2018). Exploring the possibilities of interactive audiovisual activities for language learning. Audiovisual Translation in Applied Linguistics: Beyond Case Studies, 4(1), Special issue of translation and translanguaging in multilingual contexts, 77-100.

Talaván, N. (2011). A quasi-experimental research into subtitling and foreign language education. In L. Incalterra McLoughlin, M. Biscio \& M.A. Ni Mhainín (Eds.), Audiovisual translation subtitles and subtitling (197-217). Oxford: Peter Lang.

Talaván, N. (2013). La subtitulación en el aprendizaje de lenguas extranjeras. Octaedro.

Talaván, N., \& Rodríguez-Arancón, P. (2014a). The use of interlingual subtitling to improve listening comprehension skills in advanced EFL students. In B. Garzelli \& M. Baldo (Eds.), Subtitling and intercultural communication. European languages and beyond (pp. 273-288). Pisa: InterLinguistica, ETS.

Talaván, N., \& Rodríguez-Arancón, P. (2014b). The use of reverse subtitling as an online collaborative learning tool. The Interpreter and
Translator Trainer, 8(1), 84-101. URL: https://doi.org/10.1080/1750399X.2014.908559 [10/07/19]

Talaván, N., \& Ávila-Cabrera, J. J. (2015). First insights into the combination of dubbing and subtitling as L2 didactic tools. In Y. Gambier, A. Caimi and C. Mariotti (Eds.), Subtitles and language learning, 149-172. Peter Lang.

Talaván, N., Ávila-Cabrera, J., \& Costal, T. (2016). Traducción y accesibilidad audiovisual. Editorial UOC.

Talaván, N., \& Lertola, J. (2016). Active audiodescription to promote speaking skills in online environments. Sintagma, 28, 59-74. URL: https://doi.org/10.21001/sintagma.2016.28.04 [10/07/19]

Talaván, N., \& Costal, T. (2017). iDub - The potential of intralingual dubbing in foreign language learning: How to assess the task. Language Value, 9, 62-88. URL: http://dx.doi.org/ 10.6035/LanguageV.2017.9.4 [10/07/19]

Talaván, N., Lertola, J., \& Costal, T. (2019). iCap: Intralingual captioning for writing and vocabulary enhancement. Alicante Journal of English Studies, 29, 229-248. URL: http://dx.doi.org/10.14198/raei. 2016.29.13 [10/07/19]

Thaler, E. (2014). Teaching English with films. Ferdinand Schöningh.

Vanderplank, R. (2010). Déjà vu? A decade of research on language laboratories, television and video in language learning. Language Teaching, 43(1), 1-37. URL: https://doi.org/10.1017/ S0261444809990267 [10/07/19]

Vanderplank, R. (2016). 'Effects of' and 'effects with' captions: How exactly does watching a TV programme with same-language subtitles make a difference to language learners? Language Teaching, 49(2), 235-250. URL: https://doi.org/ $10.1017 /$ S0261444813000207 [10/07/19].

José Javier Ávila-Cabrera, $\mathrm{PhD}$, works as a lecturer at the Universidad Complutense de Madrid (Spain), in the Department of English Studies. He holds a PhD in English Studies (UNED), specialising in the field of the subtitling of offensive and taboo terms. Among his academic interests are subtitling, AVT as an L2 learning tool, and the use of technology in FLL.

Pilar Rodríguez Arancón is a lecturer at UNED and her research interests are related to the intercultural aspects in the teaching of English and translation and the use of new technologies in those fields. 


\section{NOTES}

${ }^{1}$ https://www.cambridgeenglish.org/images/231794-cambridge-english-assessing-writing-performanceat-level-b1.pdf

${ }^{2}$ https://www.youtube.com/watch?v=wwkJw4Cc5YQ\&t=10s

${ }^{3}$ http://www.chinavideos.net/fjxcp/scs/82.html

${ }^{4}$ https: / / www.youtube.com/watch?v=13sSuzRZ91Y\&t=186s

${ }^{5}$ http://www.chinavideos.net/csxcp/sxs/2.html 


\section{Appendix 1}

\section{Composition 1}

Write a composition on the following topic addressing all the points below (200 words):

"In the last century, an increasing number of transportation methods have been developed. What changes have they brought to the tourism industry? Are these changes good or bad?"

Please include:

- $\quad$ Speed and safety.

- New jobs.

- Your own ideas.

\section{Composition 2}

Write a composition on the following topic addressing all the points below (200 words):

Read this paragraph in a Travel Magazine about a world-famous heritage site: "When Mount Vesuvius in the Gulf of Naples erupted in 79 AD, it buried the ancient towns of Pompeii and Herculaneum".

Choose a world heritage site in your country and write a short description.

Please include:

- A geographic description.

- Some significant dates.

- Why the site is felt to be important.

\section{Composition 3}

Write a composition on the following topic addressing all the points below (200 words):

"The success of most organizations depends on the ability of individuals to build effective teams."

Do you agree with this statement? Have you ever been to a team-building event? Describe it. If not, what do you know about them? How do you feel about them? Approach this topic from a perspective based on the tourism sector.

Please include:

- Rewards.

- Develop special relationships.

- Release energy, anger, etc. 


\section{Appendix 2}

Results of the experimental group in the subtitling tasks.

\begin{tabular}{|l|l|}
\hline Video 1 & Video 2 \\
\hline 8.5 & 6.5 \\
\hline 3.75 & 7 \\
\hline 4.5 & 4 \\
\hline 5.5 & 6.75 \\
\hline 9 & 7 \\
\hline 6.5 & 5.75 \\
\hline 6.5 & 8.5 \\
\hline 6 & 9 \\
\hline 7.5 & 8 \\
\hline 7.5 & 7.5 \\
\hline 4.75 & 6 \\
\hline 5.75 & 6.75 \\
\hline 4.5 & 6.5 \\
\hline Average & Average \\
\hline 5.9 & 7.5 \\
\hline
\end{tabular}

\section{Appendix 3}

Results of the experimental group in the writing tasks.

\begin{tabular}{|l|l|l|}
\hline Composition 1 & Composition 2 & Composition 3 \\
\hline 4.5 & 4.75 & 4.75 \\
\hline 4.5 & 4.75 & 5.5 \\
\hline 5.5 & 5 & 5 \\
\hline 7.5 & 5.5 & 8.5 \\
\hline 9.5 & 9.75 & 9 \\
\hline 4.5 & 5 & 6.75 \\
\hline 8 & 9 & 9.5 \\
\hline 4.5 & 6.5 & 6.75 \\
\hline 9.5 & 9.5 & 9.5 \\
\hline 7.5 & 8 & 7.5 \\
\hline 5.5 & 5.5 & 4 \\
\hline 4.75 & 4.5 & 5.5 \\
\hline 6.5 & 6 & 4.5 \\
\hline Average & Average & Average \\
\hline 6.326923077 & 6.442307692 & 6.673076923 \\
\hline
\end{tabular}




\section{Appendix 4}

Results of the control group in the writing tasks.

\begin{tabular}{|l|l|l|}
\hline Composition 1 & Composition 2 & $\begin{array}{l}\text { Composition } \\
\mathbf{3}\end{array}$ \\
\hline 3.75 & 4.5 & 5 \\
\hline 3 & 3 & 3 \\
\hline 9.25 & 9 & 8 \\
\hline 6 & 7 & 6 \\
\hline 9.5 & 9 & 10 \\
\hline 3.5 & 4 & 4 \\
\hline 6 & 5 & 5 \\
\hline 7 & 7.5 & 7 \\
\hline 7 & 8 & 8 \\
\hline 9.5 & 9 & 9 \\
\hline 7 & 7.5 & 7 \\
\hline 4.5 & 5 & 6 \\
\hline 4.5 & 5 & 5.75 \\
\hline 9.5 & 8 & 9 \\
\hline Average & Average & Average \\
\hline 6.428571 & 6.535714 & 6.625 \\
\hline & & \\
\hline
\end{tabular}

